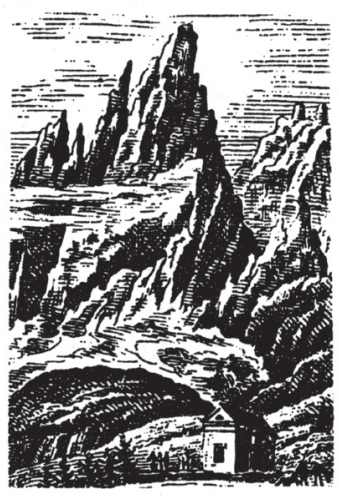

Magdalena Gołaczyńska

ORCID: 0000-0002-3628-5007

Uniwersytet Wrocławski

magdalena.golaczynska@uwr.edu.pl

DOI: $10.19195 / 2084-4107.12 .24$

\title{
Teatr Nasz w Michałowicach, czyli teatr rodzinny i wiejski
}

Słowa-klucze: Teatr Nasz w Michałowicach, Jadwiga i Tadeusz Kutowie, turystyka alternatywna, Karkonosze, teatr współczesny, teatr rodzinny, teatr wiejski, genius loci, kabaret, teatr muzyczny, komizm, śmiechoterapia

Keywords: Teatr Nasz in Michałowice, Jadwiga and Tadeusz Kuta, alternative tourism, Karkonosze, contemporary theatre, family theatre, village theatre, genius loci, cabaret, musical theatre, comedy, humor therapy

\section{Teatr Nasz in Michałowice or a family and village theatre company}

\section{Summary}

The note concerns Jadwiga and Tadeusz Kuta private theatre, Teatr Nasz (Our theatre), which performs in the Karkonosze village of Michałowice. The actors sold their possessions in the city and decided to settle in the mountains, giving up their comfortable jobs in an institutional theatre. Twenty-five years ago they erected a wooden theatre building, a restaurant and cottages for guests in Michałowice. Their spectators flee cities in order to find some rest in Michałowice, and watch cabaret, comedy and musical shows. They also undergo a humor therapy, as it were, and experience the refreshing influence of the mountains. 
Liczne ucieczki na łono natury, na wieś i w góry, pojawiały się w teatrze kontrkultury oraz później — w ostatnich latach XX wieku. Odbywały się one w dwóch wymiarach: wyjścia z teatru jako budynku oraz porzucenia cywilizacji miejskiej, także wypraw teatralnych. Tak uczynili twórcy Ośrodka Praktyk Teatralnych „Gardzienice” Włodzimierza Staniewskiego - teatr powstał pod Lublinem, a Teatr Wiejski „Węgajty” Wacława i Erdmute Sobaszków na Warmii. Po jakimś czasie na Dolnym Śląsku, na Pogórzu Izerskim, zamieszkała „Klinika Lalek” Wiktora i Joanny Wiktorczyków w Wolimierzu oraz Teatr Uliczny „Pławna 9" Dariusza Milińskiego pod Lubomierzem.

Twórcy przeciwstawiali cywilizację miejską i zgiełk ciszy górskiej, racjonalizm mieszczucha - duchowości natury, przeintelektualizowanych artystów i publiczność — „nowemu środowisku naturalnemu teatru”"1. Te wszystkie zjawiska dotyczą również Teatru Naszego z Michałowic. W latach dziewięćdziesiątych zaczęła bowiem zamierać polska kultura ludowa, gdy okazało się, że mieszkańcy wsi głównie oglądają telewizję satelitarną. W związku z tym także nowa publiczność musiała dokonać aktu przekroczenia granicy miasta i wsi.

Jadwiga i Tadeusz Kutowie, zainspirowani wczesnomłodzieńczą pamięcią Karkonoszy, powrócili do nich po ukończeniu lat trzydziestu, rozpoczynając nowy rozdział w swoich biografiach i porzucając wygodne przyzwyczajenia ${ }^{2}$. Poznali się w Jeleniej Górze, skąd wyjechali jako małżeństwo aktorskie do Torunia — tam urodziła im się córeczka Kasia i to tam zdobyli wielkie uznanie widzów teatralnych oraz dobrą nianię mieszkającą po sąsiedzku. W Toruniu mieli także mieszkanie własnościowe, samochód oraz znajomości w sklepie mięsnym i kartki na benzynę dla aktorów. Postanowili jednak sprzedać wszystko i zaryzykować — kupili trzystasześćdziesięcioletnią zrujnowaną poniemiecką chatę w Michałowicach pod Jelenią Górą. Podczas spędzanej tam pierwszej nocy Tadeusz Kuta — młody mieszczuch - napisał: „Zobaczyłem ciemność i usłyszałem CISZE... I znowu poczucie szczęścia... Jak niewiele potrzeba do SZCZĘ̧́SCIA"3. Kiedy pierwszy raz pisałam o nich artykuł i przyjechałam do Michałowic, pokazywali mi z entuzjazmem widoki z domu na strome stoki oraz malownicze lasy dostrzegalne ze wszystkich okien. (Teraz chwalą się, że proponują rozrywkę na wysokim poziomie, czyli ponad 600 metrów n.p.m.). Zachwyciłam się krajobrazami, ale w spełnienie marzeń o budowie teatru za domem nie uwierzyłam.

A jednak powstał... Początki były ekstremalne (ściana kuchni zapadła się w Wigilię) i było niewygodnie (stroma skarpa tworzyła ogródek), ale trzeba pamiętać, że prywatny Teatr Nasz założono w 1991 roku, czyli ponad dwadzieścia pięć lat temu. Kutowie chcieli mieć „swoich” widzów, którzy przyjdą dobrowolnie

1 Określenie Włodzimierza Staniewskiego, który z zachowań i pieśni ludowych czerpał artystyczną inspirację; zob. idem, Po nowe środowisko naturalne teatru, [w:] idem, Parateatr II, Wrocław 1982.

2 T. Kuta, To jest nasza Ameryka, czyli krótka historia Teatru Naszego, Michałowice 2009, s. 29.

3 Ibidem, s. 33. 


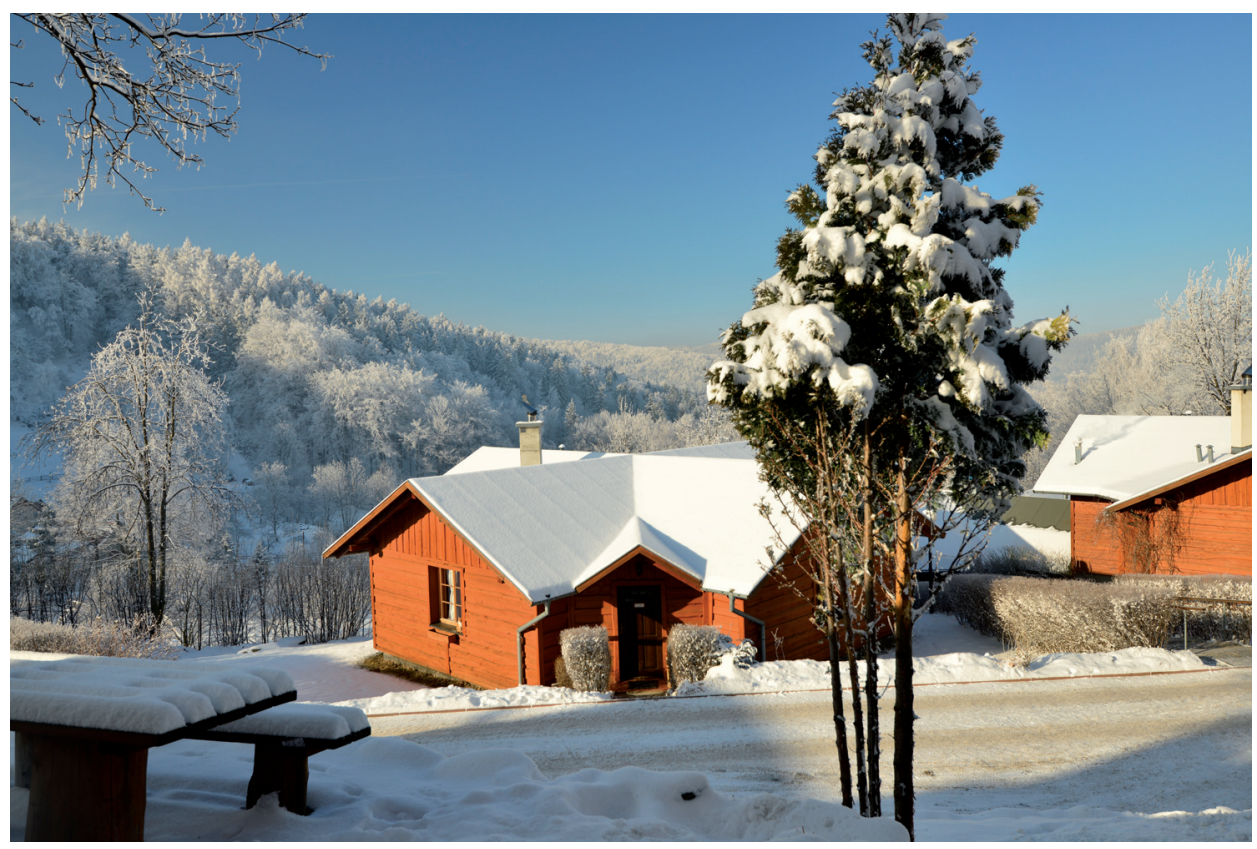

1. Teatr Nasz, domki dla gości, fot. Lilianna Sokołowska (2017)

do teatru, a słowo „nasz” w nazwie dawało publiczności poczucie związku z teatrem — to był także ,ich” teatr. Wybór niezależności twórczej oznaczał trudne bycie „na swoim”.

Wystawiali przedstawienia najpierw w domu, a następnie w amfiteatrze na łące (uroki skarpy!). We wrześniu 1997 roku Jadwiga i Tadeusz Kutowie skończyli prace nad własnoręcznie budowaną „Sceną za domem”, która była kameralną sceną w stylu górskiej, ozdobionej falbankami chaty z drewnianymi ławami i stołami dla widzów. Od początku wystawiany był lekki, autorski repertuar na poziomie profesjonalnym, czyli wieczory kabaretowe oraz spektakle komediowe i muzyczne. Jadwiga Kuta jest aktorką komediową, dramatyczną oraz śpiewającą z niezwykłym głosem, laureatką wrocławskiego Przeglądu Piosenki Aktorskiej, a jej mąż Tadeusz pisze teksty oraz występuje jako konferansjer i aktor kabaretowy ze świetną vis comica. Obecnie współtworzy z nimi kierownik muzyczny teatru, przyjaciel rodziny, multiinstrumentalista Jacek Szreniawa. Aktorzy Teatru Naszego trafili ze swoim teatrem z ogródka pod dach, do sceny z welurową kurtyną, potem doszły wizytowe stroje i tradycyjnie numerowane miejsca. W konwencję teatralnej elegancji czasami wpisują się tutaj ufryzowani i wystrojeni starsi stali widzowie, co wydaje się dość zaskakującym przebraniem w teatrze górskim, do którego wyskakuje się z samochodu na mokry parking (ach, ten klimat karkonoski!).

Część publiczności to widzowie lokalni, czyli mieszkańcy Karkonoszy: sąsiad — ksiądz Kubek (Marian Matula) z Jagniątkowa, lekarz, poeta i społecznik Kazimierz Pichlak, rzeźbiarz Zbigniew Frączkiewicz, znajoma Krystyna Czer- 
niak, a także muzycy, malarze i ludzie gór. Większość jednak przyjeżdża z miast Dolnego Śląska i całej Polski. Zwykle połowa widowni to stali widzowie, w wieku dojrzałym (około pięćdziesięcioletni). „Dzwonię, rezerwuję bilet, wsiadam w samochód i uciekam do Michałowic” — powiedzieli mi widzowie z Oławy. „Jadę naładować akumulatory" - skomentowali inni, chwaląc sobie czas na refleksję. Frekwencja jest bardzo wysoka mimo ceny biletów wynoszącej 50-70 złotych. W dodatku przed urlopami i długimi weekendami bilety należy rezerwować $\mathrm{z}$ trzytygodniowym wyprzedzeniem. Widzowie wkraczają w przestrzeń gór, porzucając cywilizację i technologię. Uciekają do wolności i ciszy ,jednego z najpiękniejszych zakątków Karkonoszy" z bliską panoramą ogromnych Śnieżnych Kotłów i prowadzącym do nich wymagającym szlakiem. Publiczność Teatru Naszego zażywa alternatywnej turystyki, powiązanej z lokalną kulturą, która zapewnia im śmiechoterapię w postaci spektakli głównie rozrywkowych. Mogą też odwiedzić pobliską widokową willę Gerharta Hauptmanna z przepiękną panoramą Karkonoszy.

Teatr Nasz to więcej niż teatr ${ }^{4}$. Widzowie po spektaklach zapraszani są na wspólne biesiadowanie w przyteatralnej gospodzie, gdzie aktorzy bywają kelnerami, oraz mają możliwość przenocować w przytulnych drewnianych domkach na łące. Mogą pozwolić sobie zatem na długotrwały, nawet kilkudniowy wypoczynek w serdecznej atmosferze. Owa serdeczność to sprawa najbardziej wyjątkowa, pozwalająca na odnowę ducha przyjezdnych. Znajdują się oni w innym czasie pozacodziennym, który ze względu na niezobowiązujący śmiech i poczucie wolności oraz „tchnienie radości” zbliża ich do „czasu karnawału”.

Spośród charakterystycznych współczesnych wątków kabaretowych Teatr Nasz wybrał tak zwane human interest, obejmujące sprawy dotyczące ludzkich osobowości i funkcjonowania człowieka w społeczeństwie, a także uniwersalny wątek seksualno-romansowy, którzy został przez nich sprawnie przekształcony w motyw małżeński. (W dialogach scenicznych wielokrotnie podkreślają, że są starym, dobrym małżeństwem aktorskim i pozwalają sobie na ironiczne docinki; w spektaklach eksploatują ponadto stereotypy dobrej żony i dobrego męża). Dodatkowym wyróżnikiem Teatru Naszego są akcenty górskie i karkonoskie.

W zakresie dowcipów społecznych w Michałowicach pojawia się ośmieszanie cech osobowych, stereotypów zawodowych, narodowych oraz instytucji, co najpełniej widać w spektaklu kabaretowym Nasza klasa (2009) — opowieści o dawnych licealistach, którzy spotykają się po wielu latach na zjeździe klasowym. Publiczności ukazuje się cała galeria rozmaitych postaci, odgrywanych głównie przez Tadeusza Kutę. Aktorzy drwią z pyszałkowatego macho, nowobogackiego niedokształconego biznesmena, szemranego terapeuty czy zarozumiałego docenta.

${ }^{4}$ Określenie Aldony Jawłowskiej, które umieściła w tytule swojej publikacji dotyczącej teatru studenckiego traktowanego jako ruch studencki; zob. eadem, Więcej niż teatr, Warszawa 1988. Sytuacja jest tu oczywiście inna — teatr alternatywny „był azylem dla nieprzystosowanych”, podczas gdy w Michałowicach mamy do czynienia z teatrem komercyjnym. Jednak i tam, i tu widz traktowany jest wyjątkowo. 


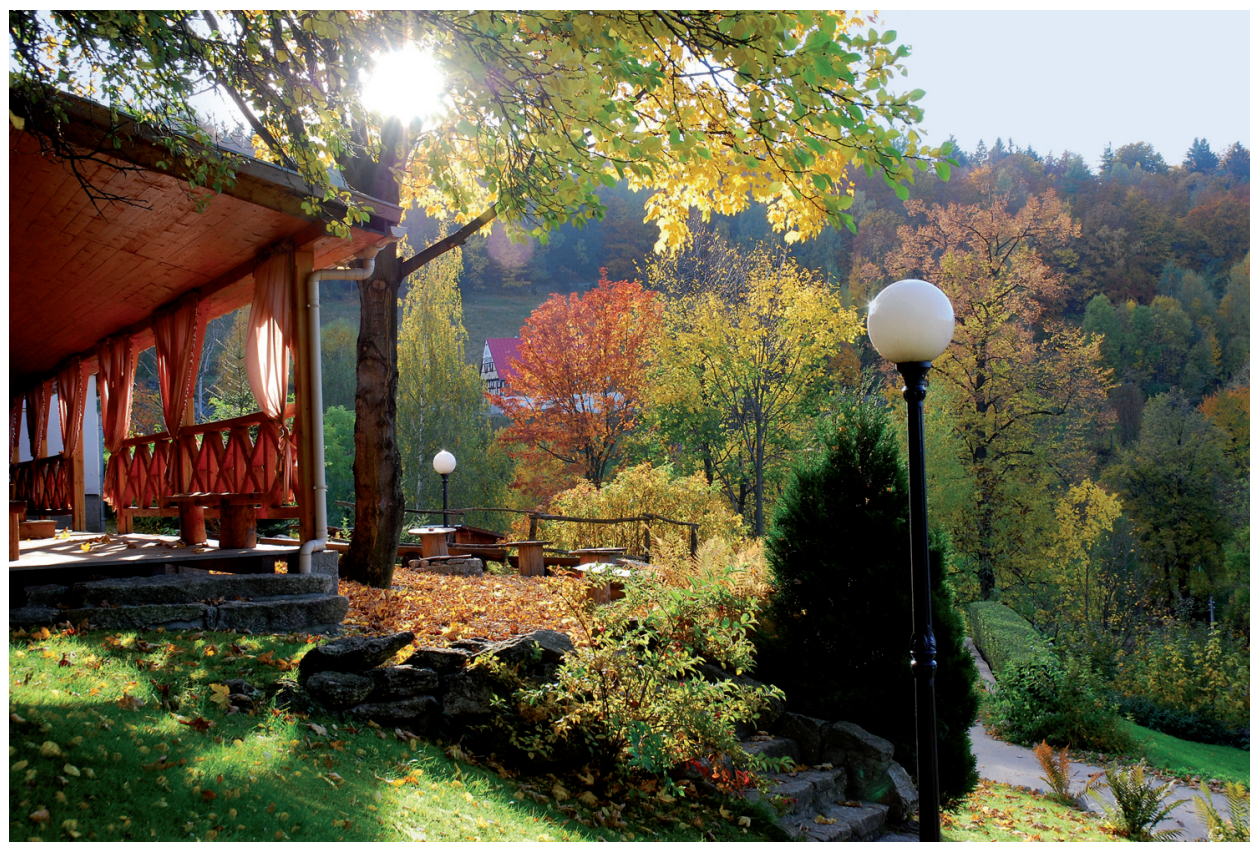

2. Teatr Nasz, Scena za domem, fot. Lilianna Sokołowska (2017)

Widz zostaje zatem postawiony w roli autorytetu — tego inteligentniejszego, lepiej wychowanego i bardziej spostrzegawczego. W monologu „Z Bobkiem w Egipcie” ukazano zamożnego i pewnego siebie Polaka Turystę (krótkie spodenki, złoty łańcuch i trzy komórki), który popada w wakacyjne tarapaty z powodu nieznajomości języków obcych. W Egipcie stwierdza, że „dookoła są same buraki, żaden po polsku nie gada"; nie może korzystać ze swojego bogactwa, ponieważ nie włożył karty do wnęki w ścianie i nie uruchomił prądu; spędza urlop w ciemności, bez klimatyzacji, popijając ciepłą „whisky” (wymowa identyczna z pisownią). Z kolei podczas wykładu z cyklu „Poznasz autoryteta z uniwersytetu” występuje zarozumiały Docent Hrabisław Rozdarło z Katedry Czynności Trudnych i Very Skomplikowanych wyjaśniający wbijanie gwoździa młotkiem, czyli „operację zgważdżania dwóch dowolnych elementów w przestrzeni”, dokonywaną przez „bijec” i końcówkę gwoździa „penetratkę”. Komizm wypowiedzi wynika z jej nadmiernej długości oraz ujmowania rzeczy banalnych w poważnym stylu.

Natomiast Jadwiga Kuta często i udanie grywa herod-baby, na przykład w Naszej klasie występuje jako zołzowata kucharka Leokadia, która własną piersią zasłania gar zupy przez brudnymi łapami uczestników zjazdu klasowego, ponieważ „byle kto nie może ingerować w cykl technologiczny żywności”. Z kolei w komedii Szczęściarze (2016) aktorka wykreowała przezabawną postać niedobrej żony. Okazuje się mianowicie, że mąż emeryt, niewychodzący z domu do pracy, będzie burzył całe jej misternie uporządkowane życie, zawadzając w licznych spotkaniach z koleżankami. 
W ulotkach czytamy, że Teatr Nasz to „kraina dobrego humoru”. Śmiechoterapia, geloterapia, czyli humor therapy, zaliczana jest do gałęzi współczesnej medycyny alternatywnej, a w Stanach Zjednoczonych zaleca się ją w szpitalach jako terapię uzupełniającą leczenie i uśmierzającą ból. Opiera się ona na założeniu, że spontaniczny śmiech pomaga odreagować stres, załagodzić konflikty i frustracje, a także służy umiejętności rozładowania napięć emocjonalnych. Skecze, monologi i piosenki Teatru Naszego wywołują głośny śmiech widowni.

Znaczenie terapeutyczne ma pierwszy stopień śmiechu, określany jako „tchnienie radości”, który można zachować jako stan permanentny, przy czym stwarza to możliwość odprężenia psychicznego oraz stanowi wyraz radosnego spokoju. Ten stopień zaczyna się już podczas podróży widzów do Michałowic, a na pewno tuż po przekroczeniu progu Teatru, podczas serdecznego osobistego powitania przez uśmiechniętych aktorów, i trwa do końca spektaklu. Przy pierwszych żartach konferansjera Kuty następuje drugi stopień śmiechu — chichot, który nie ma walorów leczniczych. Stopień trzeci to „śmiech z walorami akustycznymi”, czyli na całe gardło, któremu „towarzyszą słabsze lub silniejsze konwulsyjne ruchy ciała" (z bólami brzucha), to śmiech bardzo uzdrawiający i następuje on prawie przy każdym skeczu Kutów. Czwartym stopniem, także leczniczym, staje się śmiech do łez, nie gromki, lecz zdławiony, a nawet zduszony. Występuje w tym Teatrze często. Ruchy ciała śmiejącego stają się mimowolne, mocno nim wstrząsając ${ }^{5}$. Pod koniec przedstawienia może się niekiedy pojawić zmęczenie fizyczne. Aktorzy z Michałowic wywołują więc wszystkie z trzech stopni śmiechu niezbędnych do zapewnienia geloterapii.

Michałowice jako wiejska ojczyzna twórców i przestrzeń inspiracji odgrywają istotną rolę w widowiskach Jadwigi i Tadeusza Kutów. Używają oni przy tym malowniczych wyrażeń „Kraina dobrego humoru” i „,najpiękniejszy zakątek Karkonoszy". Dziecięcy rysunek dwóch gór - letniej i zimowej — ze słoneczkiem widoczne są w logo teatru. W 1994 roku powstało w dodatku przedstawienie Ameryka, Ameryka, czyli Country Michałowice z finałową piosenką liryczną o górach - miejscu codziennego szczęścia.

To jest nasza Ameryka, to jest nasza Ameryka,

Ptaków śpiew i drzew muzyka koi ból,

To jest nasza Ameryka, to jest nasza Ameryka,

Tu ci wraca radość życia, tylko tu!

Teatr Nasz to wyjątkowy rodzinno-przyjacielski zespół prywatny zajmujący ważne miejsce na mapie teatralnej Karkonoszy. Kabareciarze, kucharze, śmiechoterapeuci w Krainie dobrego humoru zapewniają swym gościom możliwość przekroczenia granic dnia codziennego i spędzenia kilku dni w innym czasie i miejscu.

5 Opis stadiów śmiechu za: N. Bevin, Śmiech to zdrowie. Teoria i praktyka leczniczego śmiechu, Warszawa 2002, s. 39. 


\section{Bibliografia}

Bevin N., Śmiech to zdrowie. Teoria i praktyka leczniczego śmiechu, Warszawa 2002. Jawłowska A., Więcej niż teatr, Warszawa 1988.

Kuta T., To jest nasza Ameryka, czyli krótka historia Teatru Naszego, Michałowice 2009.

Staniewski W., Po nowe środowisko naturalne teatru, [w:] idem, Parateatr II, Wrocław 1982. 